\title{
International Trade Liberalization and Protectionism: A Review
}

\author{
Jingyao $\mathrm{Fu}^{1, *}$
}

\author{
${ }^{1}$ Beijing Huijia Private School, Beijing, China \\ ${ }^{*}$ Corresponding author. Email: 22fujingyao@huijia.edu.cn
}

\begin{abstract}
Trade liberalization and protectionism have different characteristics and functions. Under the background of the epidemic outbreak and economic crisis, the global economy is affected detrimentally. How to effectively speed up economic recovery and promote future economic development through international trade liberalization and protectionism is the core content that the paper wants to explore. This paper uses the literature review method to sort out and summarize the relevant literature on international trade liberalization and protectionism. Through sorting the literature, comparatively analyzes the research status of trade liberalization, trade protectionism, and the disputes between them. The specific findings of the research are that, in general, strong countries tend to use trade liberalization while weak countries are willing to implement trade protection. Based on the epidemic situation, most countries should choose trade protectionism to protect domestic profits in the short term and continue to implement trade liberalization in the long run to promote global economic growth. In the future, countries need to strengthen cooperation in epidemic prevention, trade liberalization, and trade protection should develop in parallel to promote economic globalization.
\end{abstract}

Keywords: trade liberalization, protectionism, literature review.

\section{INTRODUCTION}

International trade is the exchange of goods and services between countries, and trade liberalization is the removal or reduction of trade barriers that block free trade between countries. It involves the elimination of tariffs, quotas, subsidies, and administrative legislation. From the 1980s, trade liberalization became increasingly popular. It was initially used as a strategy that helped ELDCs develop. In this way, many countries have moved toward liberalizing their trade and economies, including Brazil, India, Sri Lanka, and many more. From the perspective of historical development, free trade and trade protection are twin brothers, which occur alternately in the fluctuation of economic development. Generally, they are restricted by the economic strength and competitiveness of each country. The strong countries tend to trade freely, while the weak countries tend to trade protection. With the development of the economy and the difference of times, the characteristics of trade liberalization and trade protectionism are also changing. In particular, the outbreak of the U.S. subprime mortgage crisis in 2008 has seriously affected the global economy. The real economic and political crises of various countries have followed. To maintain their own social and political stability, countries worldwide have introduced various rescue and stimulus programs. Trade protectionism also has some characteristics different from before. One is deep-seated, the other is global, the third is hypocrisy, the fourth is diversity, and the fifth is complexity [1]. From the perspective of theory and practice, Global trade liberalization is the direction of development and the general trend. In theory, free trade is the way with the least cost and the greatest benefit. In terms of international trade theory, trade liberalization or free trade is always welfare maximization. Any measures and policies to restrict trade are harmful to our own country and the welfare level of other countries [2]. At present, there are many theories about the liberalization of international trade, such as David Ricardo's comparative advantage theory and Herschel Orin's factor endowment theory. The trend of Global trade liberalization is not irresistible. Still, at the same time, due to various reasons, this trend also affects the economic development of a country, especially the developing countries. If trade liberalization and protectionism are weighed against the background of global economic integration, each country 
should consider the main problem. Since entering the 21 st century, the continuous strengthening of economic globalization and regional economic integration, especially China's emerging trade market, has become a new favorite in international trade. All countries want to share economic benefits from the tide of globalization and promote the rapid development of their trade. While protectionism is the placement of legal restrictions on international trade and includes tariffs, quotas, subsidies, and other bureaucratic barriers. Protectionism is started from Mercantilism, which is the first economic theory of the bourgeoisie. Mercantilism came into being and prevailed in Western Europe from the 15th century to the middle of the 17th century. Its developments goal is national prosperity and strength. In the 1970s, new protectionism occurred. At that time, with the rapid economic development of some Western European countries, the increasing competition forced the United States to seek strategies to protect its interests. Therefore, new protectionism was born. New protectionism is different from the previous strategy of imposing tariffs. It aims to protect domestic enterprises, produce more exports, and reduce imports. It is an innovation of trade protectionism. Economic globalization is also a "doubleedged sword". The countries enjoy the benefits in the process of international trade but also bear the resulting harm. Therefore, the novel coronavirus pneumonia outbreak has attracted more and more attention of countries to maintain their own economic interests, especially the international trade liberalization and the trade protectionism.

During the covid-19 pandemic, the economies of countries around the world are all negatively affected. In this case, to speed up the recovery of the global economy, all parties have stressed their opposition to trade protectionism. In early June, the APEC meeting of trade ministers issued a statement saying that trade facilitation measures will be taken to promote the cross-border flow of vaccines and related products to combat the epidemic and promote economic recovery. Under the epidemic situation, all of the countries should consider what kind of goal they should pursue? Through what means to achieve their goals? Further, opening up free trade or proper trade protection? What is the most favorable direction for the development of trade relations between countries? Based on this, we have made the dialectical relationship analysis of the liberalization and protectionism of international trade at present, trying to find the international strategy that is more conducive to the country's development. Therefore, this paper wants to summarize the current research results, compare and analyze the current research status of trade liberalization and trade protectionism, and point out the possible development direction of countries in international trade relations in the future.

\section{LITERATURE REVIEW}

At present, there are more and more researches on trade protectionism and trade liberalization. From the CNKI database, the paper searched the literature published in recent years about the keywords of "trade protection" and "trade liberalization". Figure 1 and Figure 2 respectively show the number of papers published since 2012 about the keywords of "trade protection" and "trade liberalization". As shown in figures 1 and 2, there are abundant research results on trade protectionism and trade liberalization. The number of trade protectionism research peaked in 2018, mainly related to the US subprime crisis at the end of 2017. In the research on trade liberalization, the number of papers peaked in 2015, reaching 548, decreasing in 2016. However, it still maintained a high number, further highlighting the importance of studying the dialectical relationship between trade protection and trade liberalization.

Based on this literature, the paper sorts out and classifies the existing related research and selects 27 papers with high correlation to sort out and explain. The details are shown in Table 1. The publication date and title of the paper is shown. Consequently, the related references in detail will be analyzed in this paper.

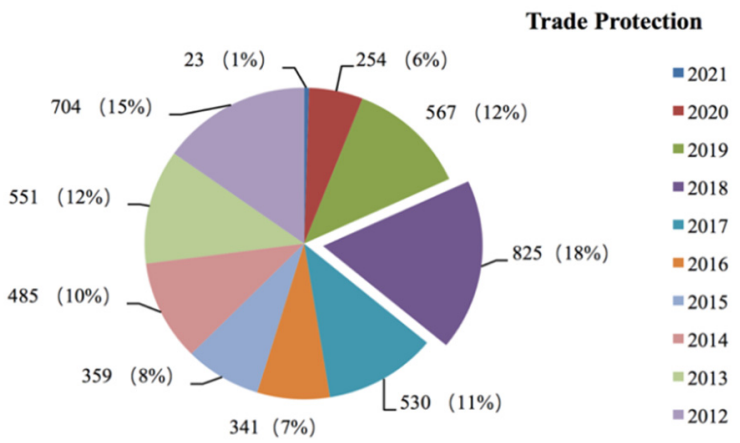

Figure 1 The number of papers published on the keyword "Trade Protection" from 2012 to 2021

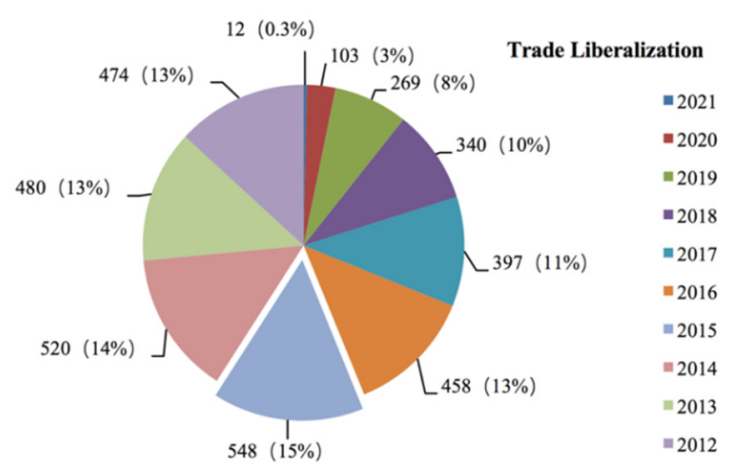

Figure 2 The number of papers published on the keyword "Trade Liberalization" from 2012 to 2021 
Table 1. Classification of References

\begin{tabular}{|c|c|c|c|c|c|}
\hline Num. & Date & Title & Num. & Date & Title \\
\hline 1 & 2003 & $\begin{array}{l}\text { The trend of new liberalism in } \\
\text { international trade policy. }\end{array}$ & 15 & 2010 & $\begin{array}{l}\text { "carbon tariff": a new form of trade } \\
\text { protection. }\end{array}$ \\
\hline 2 & 2005 & $\begin{array}{l}\text { The causes and characteristics of the } \\
\text { development of the world bilateral free } \\
\text { trade and the Countermeasures of } \\
\text { China. }\end{array}$ & 16 & 2010 & $\begin{array}{l}\text { The impact of global trade protectionism on } \\
\text { China's export trade and Countermeasures } \\
\text { under the financial crisis. }\end{array}$ \\
\hline 3 & 2005 & $\begin{array}{l}\text { Trade liberalization and income } \\
\text { inequality: Based on China's empirical } \\
\text { study. }\end{array}$ & 17 & 2012 & $\begin{array}{l}\text { New characteristics of current } \\
\text { protectionism in international trade and } \\
\text { China's countermeasures. }\end{array}$ \\
\hline 4 & 2007 & $\begin{array}{l}\text { The relationship between the } \\
\text { liberalization of service trade and } \\
\text { economic growth in China: Analysis } \\
\text { Based on impulse response function } \\
\text { method. }\end{array}$ & 18 & 2014 & $\begin{array}{l}\text { Research on the change of trade } \\
\text { protectionism and trade protection policy. }\end{array}$ \\
\hline 5 & 2015 & $\begin{array}{l}\text { On the liberalization of international } \\
\text { trade and China's countermeasures. }\end{array}$ & 19 & 2016 & $\begin{array}{l}\text { Trade protectionism: under barriers, global } \\
\text { trade is recovering hard. }\end{array}$ \\
\hline 6 & 2020 & $\begin{array}{l}\text { Trade liberalization and employment } \\
\text { level: theoretical and empirical research } \\
\text { based on the structural model. }\end{array}$ & 20 & 2019 & $\begin{array}{l}\text { The study on the impact of trade protection } \\
\text { on global investment and economic growth. }\end{array}$ \\
\hline 7 & 2020 & $\begin{array}{l}\text { The impact of trade liberalization on the } \\
\text { income gap between urban and rural } \\
\text { areas in China. }\end{array}$ & 21 & 2020 & $\begin{array}{l}\text { The change of economic globalization } \\
\text { under the epidemic. }\end{array}$ \\
\hline 8 & 2020 & $\begin{array}{l}\text { Trends and problems of global trade } \\
\text { liberalization. }\end{array}$ & 22 & 2020 & $\begin{array}{l}\text { The root causes of the prevalence and } \\
\text { development of trade protectionism. }\end{array}$ \\
\hline 9 & 2020 & $\begin{array}{l}\text { Trade liberalization and welfare effects: } \\
\text { a literature review. }\end{array}$ & 23 & 2020 & Trade protectionism and its impact. \\
\hline 10 & 2020 & $\begin{array}{l}\text { Novel coronavirus pneumonia impact } \\
\text { on Global trade and coping strategies. }\end{array}$ & 24 & 2004 & $\begin{array}{l}\text { Game Analysis of trade liberalization and } \\
\text { protectionism -- on why unilateral trade } \\
\text { liberalization is difficult to move. }\end{array}$ \\
\hline 11 & 2008 & $\begin{array}{l}\text { Characteristics, causes, and trends of } \\
\text { the development of new trade } \\
\text { protectionism. }\end{array}$ & 25 & 2006 & $\begin{array}{l}\text { The debate between free trade and } \\
\text { protectionism in the present era: a } \\
\text { theoretical review. }\end{array}$ \\
\hline 12 & 2008 & $\begin{array}{l}\text { The development trend of trade } \\
\text { protectionism. }\end{array}$ & 26 & 2010 & $\begin{array}{l}\text { Historical choice of protectionism and trade } \\
\text { freedom from a cultural perspective. }\end{array}$ \\
\hline 13 & 2010 & $\begin{array}{l}\text { The rise of protectionism in } \\
\text { international trade and China's } \\
\text { countermeasures. }\end{array}$ & 27 & 2011 & $\begin{array}{l}\text { Protection and freedom in international } \\
\text { trade theory: analysis from the perspective } \\
\text { of national interests. }\end{array}$ \\
\hline 14 & 2010 & $\begin{array}{l}\text { A study of new international trade } \\
\text { protectionism in the post financial } \\
\text { crisis. }\end{array}$ & & & \\
\hline
\end{tabular}

\subsection{Research on Trade Liberalization}

Huang Jingbo examines the practice of Neoliberalism trade policy and further explores the methodological characteristics of Neoliberalism trade policy theory. Understanding the Neoliberalism trade policy theory is of great significance to China's opening up and integration into the world economy [3]. Marked by the rapid development of global FTA, especially bilateral free trade, and based on the regionalization of the world economy, Liu Changli analyzes the new features of trade liberalization at this stage and points out that the new stage of free trade is not accidental. However, the inevitable result of the development of current international economic and trade relations. In this regard, China must grasp the development of the FTA strategy and take a forward-looking attitude towards bilateral free trade [4]. Dai Feng used theoretical models and modern econometrics research methods to conduct an empirical analysis of the relationship between China's trade liberalization and income inequality and verified the causal relationship between the two. Finally, the article further analyzes the main ways that trade liberalization affects income inequality to attract the attention of relevant departments and take some measures to alleviate the inequality in income distribution from the perspective of trade [5]. Shang Tao, Guo Genlong, and Feng Zongxian used the impulse response function method and variance decomposition method based on the VAR model to investigate the long-term dynamic impact characteristics of China's import and export on service trade and China's economic development from 1982 to 2004. The analysis results show that, on the one hand, the import and export of service trade is an important factor affecting China's economic growth; on the other hand, economic growth also has a reverse effect on economic development. However, the latter has a certain lag effect. The results of variance decomposition show that 
liberalization on trade in service is an important variable to explain the prediction variance of economic growth. Still, the contribution of economic growth to the prediction variance of service trade liberalization is relatively small, and the promotion mechanism of economic growth to service trade still needs to be further improved [6]. Yang Jianguo briefly introduced the characteristics of international trade liberalization and analyzed China's countermeasures [7]. Wang Xiaosong and others based on the general equilibrium quantitative model include intermediate product trade, final product trade, industry heterogeneity, and input-output relationship. They can obtain an equilibrium equation that quantifies a country's employment level. Using the extended input-output model, the key coefficients of the above equations are obtained, and the relationship between trade liberalization and employment level is analyzed. In the future, China can adopt targeted trade policies for specific industries to cope with the negative effects of the outbreak of trade war and the outbreak of COVID-19 to achieve stable employment. [8]. Based on the Heckscher Ohlin model, You Maoqun and Fei Yuanxin have made a theoretical analysis of the impact of trade liberalization on the income gap between urban and rural areas in China. Today, it is proposed to reduce the income gap between China and urban areas, coordinate the relationship between free trade and residents' income gap, and benefit from free trade between different regions in China. More reasonable and even distribution between urban and rural areas, adherence to opening up, establishing new bonded ports and free trade zones, and more comprehensive integration into the global production network. Meanwhile, while encouraging exports, we should also pay attention to imports to ensure the relative balance of import and export trade to promote the sustainable development of foreign trade [9]. Based on the current development trend of world trade liberalization, Zhang Niannian, Ling $\mathrm{Hu}$, and Ji Nana discussed the measures China should take in the process of international trade in the future [10]. Through a systematic review of the existing literature, Li Jingbo summarized the relevant research from theoretical and empirical perspectives and pointed out the shortcomings of the existing models and the possible future research directions [11]. Liu Jiayao analyzes the global trade situation and the decline of production capacity and consumption ability based on the outbreak of the COVID-19 situation. The outbreak of COVID-19 has been described as a dilemma between the supply side and demand side of global trade. Finally, it is proposed that all countries should strengthen cooperation in the prevention and control of epidemic diseases, promote in-depth consultation on multilateral trade, promote regional trade liberalization and facilitation, and open up new trade growth points [12].

\subsubsection{Research on Trade Protectionism}

Wang Diankai thinks that compared with traditional trade protectionism, the new trade protectionism has different characteristics. The emergence and development of China's foreign trade are due to both the multilateral trading system and the theoretical development. The imbalance of economic development of various countries is the deep reason for its emergence and development. New trade protectionism will continue to exist in the current economic environment and become more intense. Trade liberalization and trade protection will be intertwined, which will be the normal development of international trade [13]. Xu Jie pointed out that the purpose of trade protectionism is to protect the domestic market from the competition of foreign goods, to protect domestic employment, and to maintain its dominant position in the international division of labor and international exchange. Today's trade protectionism mainly manifests in green barriers, technical barriers, anti-dumping, intellectual property protection, and other non-tariff barriers. Under the banner of safeguarding national interests and protecting resources and the environment, they are characterized by nominal rationality, formal concealment, deception in means, and offensive strategy. China should adopt corresponding strategies [14]. Zhang Xiangchen analyzed that although the financial crisis led to the ferocious trend of international trade protectionism, there was no high-intensity wave of trade protection. China has become the main target of trade protectionism and is facing an unprecedented severe situation in dealing with trade frictions. China has effectively dealt with trade frictions by relying on the WTO mechanism and other measures, but it needs to be highly alert to the RMB exchange rate and carbon tariffs. With the increasing influence on the world economy, China must keep expanding its opening-up to realize its sustainable development in the struggle against trade protectionism [15]. Wu Guihua analyzed the reasons for the prevalence of new international trade protectionism in the post financial crisis period. He pointed out the new trend and harm of its development, revealed the essence of the game between international trade protection and antiprotection, and put forward the idea of responding to the new international trade protectionism effectively and calmly in the post financial crisis period [16]. Chen Jiemin and Wang Qin analyzed the issue of "carbon tariff," one of the controversial focuses at the world climate conference in Copenhagen in 2009. They pointed out that some developed countries are ready to impose "carbon tariff" on the export products of countries that have not taken measures to implement emission reduction targets" The essence of "carbon tariff" is that developed countries link climate issues with trade issues and implement trade protectionism in the name of environmental protection Once the "carbon tariff" is imposed, it will have an impact on China's exports, and 
China should take measures as soon as possible [17]. Taking the global financial crisis caused by the U.S. subprime mortgage problem in 2007 as the background, Zhang Wenhu pointed out that some countries have taken trade protectionism measures. It has had a certain negative impact on the healthy development of China's import and export trade. The development ideas and corresponding strategies of China's import and export trade are put forward [18]. Shao Weihua pointed out that there are still many uncertain and unstable factors in the world economy in the post-crisis era. To stimulate economic growth and protect employment, trade protectionism is once again popular and presents new characteristics. China should protect the interests of enterprises; Improve the quality of export products and promote the upgrading of products; Enterprises should cooperate in operations; To promote economic integration and build harmonious economic and trade relations to actively respond to international trade protectionism [19]. Through the further understanding of trade protectionism and the comparative analysis of various data, Ji Lilin finds the change characteristics of trade protection policies adopted by various countries since the financial crisis, to find a compromise point for the current trade protectionism of various countries, and play a certain reference role for the recovery of free trade among countries in the world and better make the world economic recovery [20]. Xu Xiujun pointed out that both for developed economies and emerging market economies, trade protectionism measures are increasing, and the process of Global trade liberalization is very slow, which makes the difficult recovery of Global trade even worse. The world economy is still in the stage of deep adjustment after the international financial crisis. Under this background, the development of global trade is still facing severe challenges from the external environment, and the situation of foreign trade is more complicated. Whether for developed economies or emerging market economies, trade protectionism is still prevalent, while the process of trade liberalization is very slow [21]. Zhang Xinping believes that the global economy has entered a stage of rapid development, and major changes will take place in the world economic structure. Moreover, the reform of the global multilateral trade system is in full swing. The trading system tends to be fair, the trading system is more protective, and digital trade rules are promoted [22]. Wang Jun and Liang Rong jointly analyzed the impact of the epidemic situation on economic globalization. They believed that the epidemic situation strengthened the momentum of trade protectionism again, but it would not weaken the advantage of China's supply chain. We should promote a new round of globalization with stronger global cooperation [23]. Based on the current economic background, Xiong Guangqing analyzed that the current trade protectionism has a strong public opinion foundation, spread in many countries in the United States and Europe, and broke through the shackles of the multilateral trade system [24]. Liu Yeqing and Cui Qiang took the world economic situation with increasing trade frictions as the background. To correctly understand the current situation and existing problems of China's foreign trade, understand the impact of the rise of trade protectionism on China's foreign trade development, and actively explore countermeasures is the top priority to maintain sustainable development of China's foreign economy [25].

\subsubsection{Disputes on Trade Liberalization and Trade Protectionism}

From the perspective of the static game, Zhou Maorong and Du Li proved that any country's attempt to implement unilateral liberalization is very difficult to succeed. In the short term, all countries will choose protective trade policies for the sake of maximizing their own interests [26]. Ping Xinqiao analyzed in detail the two main viewpoints in the current international trade; The moderate trade protection theory and the comparative advantage free trade theory based on outsourcing. Although the moderate trade protection theory represented by Samuelson is more profound, it also has obvious limitations. That is, it ignores the transnational division of labor. However, when the vertical division of labor in the production process has been increasingly developed, a country's efforts to find its own comparative advantage should go deep into the industry. On the one hand, we should pay close attention to the transfer trend of intra industry division to fully use the advantages of intra industry division. On the other hand, efforts should be made to change the country's situation at the low end of the industrial value chain [27]. Through empirical and normative analysis, $\mathrm{Lin} \mathrm{Li}$ and Yan Wei proved that economic globalization and world trade positively affect world cultural diversity [28]. Chen Chen systematically combed the relevant discourses on "protection" and "freedom" of international trade theories in various times from the perspective of national interests and drew three basic conclusions: first, no matter trade protection or trade freedom, they cannot bring win-win results to the world; second, they cannot bring win-win results to the world; Secondly, trade protection and trade freedom are the rhetoric of different sovereign countries to safeguard their own economic interests, and there is no standard right and wrong judgment standard for them; Finally, both trade protection and trade freedom have periodical and historical characteristics [29].

\section{CONCLUSION}

By reading the relevant scholars' literature on trade liberalization and trade, protectionism debates have given this paper a lot of inspiration in the past two decades. In the research process, this paper found that the current research on international trade relations is becoming more and more important. The outbreak of the epidemic 
and the occurrence of the economic crisis have made the international trade environment more cautious. In this context, this paper has sorted out and classified the existing research, and analyzed the research on trade liberalization and trade protectionism through comparative analysis, and pointed out the possible development direction of various countries in international trade in the future. Specifically, it can be summarized as follows.

On the one hand, In the background of the outbreak of the COVID-19 epidemic and the economic crisis, economic globalization has been impacted. In the short term, countries should choose trade protectionism policies for the sake of maximizing their own profits. Since there are still many uncertain factors in the world economy and the decline in production and consumption capacity of countries during the epidemic situation, trade protectionism should be implemented in the short term to stimulate economic growth and protect employment to better recover the world economy. Especially for China, the government should protect the profits of enterprises and promote the upgrading of products. Such as, once the "carbon tariff" is imposed, China's exports will have an impact, China should take measures as soon as possible to effectively and calmly deal with the new international trade protectionism and build a harmonious economic and trade relationship.

On the other hand, both trade protection and trade liberalization have historical features, and the parallel development of trade liberalization and trade protection will be the norm of international trade development. It is necessary and important to persist in advancing economic globalization and world trade in the long run. Import and export of service trade is an important factor affecting China's economic growth. China can also take some measures to mitigate the unequal distribution of income from the perspective of trade and adapt targeted trade policies for specific industries to cope with the negative effects of the outbreak of trade war and the outbreak of the epidemic to achieve stable employment. Meanwhile, countries should also focus on imports while encouraging export to ensure the relative balance of import and export trade. Faced with the epidemic's impact, countries need to strengthen cooperation in epidemic prevention and control and promote trade liberalization to promote economic development.

\section{REFERENCES}

[1] Xue Rongjiu. (2009). Characteristics, harm and containment of trade protectionism under economic globalization. International trade (03), 28-31

[2] Guanquan (2018). Trends and problems of Global trade liberalization. People's forum, academic frontier, 000 (020), 4-17
[3] Huang Jingbo. (2003). The trend of new liberalism in international trade policy. Journal of Zhongshan University (SOCIAL SCIENCE EDITION) (01), $70-77$

[4] Liu Changli. (2005). The causes and characteristics of the development of the world bilateral free trade and the Countermeasures of China. World Economic Research (04), 4-10

[5] Dai Feng. (2005). Trade liberalization and income inequality: Based on China's empirical study. World Economic Research (10), 39-46

[6] ShangTao, Guo Genlong, Feng Zongxian. (2007). The relationship between the liberalization of service trade and economic growth in China: Analysis Based on impulse response function method. International trade problem (08), 92-98

[7] Yang Jianguo (2015). On the liberalization of international trade and China's countermeasures. Decision making and information periodical appearing once every ten days (8)

[8] Wang Xiaosong, Zhang Yimeng, Tian Siyuan. (2020). Trade liberalization and employment level: theoretical and empirical research based on structural model. Journal of Wuhan University (PHILOSOPHY AND SOCIAL SCIENCES EDITION), v.73; No.370(05), 107-123.

[9] You Maoqun, Fei Yuanxin. (2020). The impact of trade liberalization on the income gap between urban and rural areas in China. Chinese civil commerce, 000 (001), p.133-133

[10] Zhang Niannian, Ling Hu, Ji Nana. (2020). Trends and problems of Global trade liberalization. Marketing (28), 34-35

[11] Li Jingbo. (2020). Trade liberalization and welfare effects: a literature review. Foreign trade, 000 (001), p.51-54

[12] Liu Jiayao. Novel coronavirus pneumonia impact on Global trade and coping strategies. Prices Monthly, 2020, (7): 90-94.

[13] Wang Diankai. (2008). Characteristics, causes and trends of the development of new trade protectionism. Journal of Capital University of economics and trade (4)

[14] Xu Jie. (2008). The development trend of trade protectionism. Journal of Daqing Normal University (04), 30-33

[15] Zhang Xiangchen. The rise of protectionism in international trade and China's countermeasures. China International Strategic Review (2010 (general issue 3)) 
[16] Wu Guihua. (2010). A study of new international trade protectionism in the post financial crisis. Jiangxi Social Sciences (06), 65-70

[17] Chen Jiemin, Wang Qin. (2010) "carbon tariff": a new form of trade protection. Heilongjiang foreign trade and trade (4), 30-31

[18] Zhang Wenhu. (2010). The impact of Global trade protectionism on China's export trade and Countermeasures under the financial crisis. Chinese business (02), 8-9

[19] Shao Weihua. (2012). New characteristics of current protectionism in international trade and China's countermeasures. Foreign trade and trade, 000 (003), 22-23

[20] Ji Lilin (2014). Research on the change of trade protectionism and trade protection policy. Modern enterprise education, no.467 (24), 522-523

[21] Xu Xiujun. (2016). Trade protectionism: under barriers, the global trade is recovering hard. Contemporary financiers, 04 (No.130), 117-119

[22] Zhang Xinping. (2019). The study on the impact of trade protection on global investment and economic growth. Xinsi Road: the first ten days, 000 (003), 11
[23] Wang Jun, Liang Rong. (2020). The change of economic globalization under the epidemic. Tsinghua Financial Review (6)

[24] Xiong Guangqing. (2020). The root causes of the prevalence and development of trade protectionism. People's forum, no.657 (03), 36-39

[25] Liu Yeqing, Cui Qiang. (2020). Trade protectionism and its impact. Cooperative economy and technology, no.646 (23), 86-87

[26] Zhou Maorong, Du Li. (2004). Game Analysis of trade liberalization and protectionism -- on why unilateral trade liberalization is difficult to move. International trade issues (6), 17-19

[27] Ping Xinqiao. (2006). The debate between free trade and protectionism in the present era: a theoretical review. Comparison of economic and social systems, 000 (002), 28-34

[28] Lin Li, Yan Wei. (2010). Historical choice of protectionism and trade freedom from a cultural perspective. Frontier, 000 (003), 65-68

[29] Chen Chen. (2011). Protection and freedom in international trade theory: analysis from the perspective of national interests. Claim, 000 (009), 47-48 